
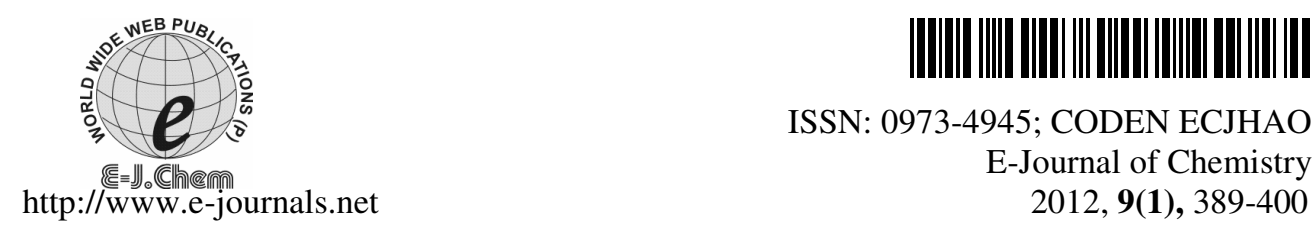

ISSN: 0973-4945; CODEN ECJHAO

E-Journal of Chemistry 2012, 9(1), 389-400

\title{
Synthesis, Characterization, Biological Activity and DNA Binding Studies of Metal Complexes with 4-Aminoantipyrine Schiff Base Ligand
}

\author{
B.ANUPAMA, M. PADMAJA and C.GYANA KUMARI* \\ Departrment of Chemistry, Osmania University \\ Hyderabad -500007, India \\ prof_c_gyana@yahoo.co.in
}

Received 29 May 2011; Accepted 5 August 2011

\begin{abstract}
A new series of transition metal complexes of $\mathrm{Cu}(\mathrm{II}), \mathrm{Ni}(\mathrm{II}), \mathrm{Co}(\mathrm{II})$, $\mathrm{Zn}(\mathrm{II})$ and $\mathrm{VO}(\mathrm{IV})$ have been synthesized from the Schiff base ligand (L) derived from 4-amino antipyrine and 5- bromo salicylaldehyde. The structural features of Schiff base and metal complexes were determined from their elemental analyses, thermogravimetric studies, magneticsusceptibility, molar conductivity, ESI-Mass, IR, UV-VIS, ${ }^{1} \mathrm{H}$ NMR and ESR spectral studies. The data show that the complexes have composition of $\mathrm{ML}_{2}$ type. The UV-VIS, magnetic susceptibility and ESR spectral data suggest an octahedral geometry around the central metal ion. Biological screening of the complexes reveals that the Schiff base transition metal complexes show significant activity against microorganisms. Binding of Co(II) complex with calf thymus DNA (CT DNA) was studied by spectral methods.
\end{abstract}

Keywords: Aminoantipyrine, Schiff base, complex, Antimicrobial studies, DNA binding

\section{Introduction}

Antipyrine derivatives are reported to exhibit analgesic and anti -infammatory effects ${ }^{1-4}$, antiviral $^{5}$, antibacterial ${ }^{6}$ activities and have also been used as hair colour additives $^{7}$ and to potentiate the local anesthetic effect of lidocaine ${ }^{8}$. These compounds have been used in spectrophotometric determination of metal ions. Many of these reagents give intense colours with transition metal ions, providing sensitive probes ${ }^{9}$ and some of them can also coordinate to rare earth ions to form metal complexes with interesting structures ${ }^{10}$. Antipyrine Schiff base derivatives can serve as antiparasitic agents and their complexes with platinum(II) and cobalt(II) ions have been shown to act as antitumour substances ${ }^{11}$ A search through the literature reveals that no work has been done on the transition metal complexes of Schiff base formed by the condensation of 4-aminoantipyrine with 5-bromo salicylaldehyde. In the 
present context, we synthesized tridentate ligand system from 4-aminoantipyrine and 5-Br salicylaldehyde. The synthesized compound and its ligation behaviour with metal ions was studied.

\section{Experimental}

All the chemicals used were of analar grade. 4-Aminoantipyrine, metal salts and 5-bromo salicylaldehyde were obtained from Sigma Aldrich. Solvents such as ethanol, methanol, petroleum ether were purified by standard procedures.

\section{Instruments}

Elemental analysis of the ligands and their metal complexes was carried out using a PerkinElmer 240C (USA) elemental analyser. Molarconductances of the metal complexes were measured in a DMSO solution using digisun electronic conductivity meter. Magnetic susceptibilities of the complexes were determined on Guoy balance, model 7550 using $\mathrm{Hg}$ $\left[\mathrm{Co}(\mathrm{NCS})_{4}\right]$ as standard. The diamagnetic corrections of the complexes were done using Pascal's constants. TGA studies were carried on Shimadzu DTG $-60 \mathrm{H}$ system in the temperature range of $0-1000{ }^{\circ} \mathrm{C}$.

IR spectra were recorded in $\mathrm{KBr}$ discs on Brucker FTIR spectrophotometer from 400 to $4000 \mathrm{~cm}^{-1}$. Electronic spectra were recorded with an Elico SL $159 \mathrm{UV}$ visible spectrometer from $200-1100 \mathrm{~nm} .{ }^{1} \mathrm{H}$ NMR \& ${ }^{13} \mathrm{C}$ NMR spectra were recorded using $\mathrm{CDCl}_{3}$, at Brucker $400 \mathrm{MHZ}$ spectrometer. The mass spectra were recorded by ESI technique on LCQ ion trap (thermo Finningan Sanjose CA (USA) mass spectrometer instrument. The ESR spectra of the Cu(II) complexes were recorded on Jeol, JES -A 200 ESR spectrometer at room temperature.

\section{Synthesis of Schiff base(5-Br SALAAP) ligand}

The 5-bromo salicylidene-4-aminoantipyrine(5-Br SALAAP) was prepared by using the reported method ${ }^{12}$. 4-Aminoantipyrine $(2.03 \mathrm{~g} 0.01 \mathrm{mmol})$ and 5-bromo salicylaldehyde (2.01 g $0.01 \mathrm{mmol})$ were dissolved in a methanol solution. The mixture was stirred for $30 \mathrm{~min}$ at room temperature to give a yellow precipitate. The mixture was filtered and the solid obtained was recrystallised from methanol solution.

\section{Synthesis of metal complexes}

In the preparation of the metal complexes, the metal and the ligands were mixed in 1:2 molar ratio using required quantities of ethanol. Hot ethanolic solution of ligand $(0.01 \mathrm{~mol})$ and hot ethanolic solution of corresponding metal salts $(0.01 / 0.005 \mathrm{~mol})$ $\left(\mathrm{MX}_{2}\right.$ where $\mathrm{M}=\mathrm{Cu}(\mathrm{II}), \mathrm{Ni}(\mathrm{II}), \mathrm{Co}(\mathrm{II}), \mathrm{Zn}(\mathrm{II})$ and $\mathrm{VO}(\mathrm{IV}) \mathrm{X}=\mathrm{Cl}$; for $\mathrm{VO}(\mathrm{IV}) ; \mathrm{X}=\mathrm{SO}_{4}$ ) were mixed together, refluxed for 2-3 h and left for evaporation at room temperature for 3 days, coloured solid metal complexes were obtained. The products were filtered, washed with cold ethanol and dried under vacuum over calcium chloride.

\section{DNA binding activity}

Absorption spectra were reorded on a UV-Visible spectrophotometer using $1 \mathrm{~cm}$ quartz micro cuvettes. Absorption titrations were performed by keeping the concentration of the complex constant $(100 \mu \mathrm{M})$ and by varying the concentration of CT -DNA from 0-40 $\mu \mathrm{M}$. The binding constant $\left(\mathrm{K}_{\mathrm{b}}\right)$ for the binding of the complex with DNA, has been determined from the spectroscopic titration data using the following equation.

$$
[\mathrm{DNA}] /\left(\varepsilon_{\mathrm{a}}-\varepsilon_{\mathrm{f}}\right)=[\mathrm{DNA}] /\left(\varepsilon_{\mathrm{b}}-\varepsilon_{\mathrm{f}}\right)+1 / \mathrm{K}_{\mathrm{b}}\left(\varepsilon_{\mathrm{b}}-\varepsilon_{\mathrm{f}}\right)
$$


Where [DNA] is the concentration per nucleotide,the apparent extinction coefficient $\varepsilon_{\mathrm{a}}$, was obtained by calculating $\mathrm{A}_{\mathrm{obs}} /[\mathrm{Co}(\mathrm{II})], \varepsilon_{\mathrm{f}}$ extinction coefficient of the complex in presence of DNA and $\varepsilon_{\mathrm{b}}$ the extinction coefficients for the fully $\mathrm{Co}$ (II) complex in the fully bound form. $\mathrm{K}_{\mathrm{b}}$ (binding constant) the ratio of the slope to the intercept , was obtained from a plot of [DNA] $/\left(\varepsilon_{\mathrm{a}}-\varepsilon_{\mathrm{f}}\right)$ versus [DNA], a slope $1 /\left(\varepsilon_{\mathrm{b}}-\varepsilon_{\mathrm{f}}\right)$ and an intercept $1 / \mathrm{K}_{\mathrm{b}}\left(\varepsilon_{\mathrm{b}}-\varepsilon_{\mathrm{f}}\right)$.

\section{Results and Discussion}

\section{Characterization of ligand}

Synthesized Schiff base ligand (L) (2,3-dimethyl-1-phenyl-4-(5-bromo-2-hydroxy benzylideneamino)-pyrazol-5-one) is yellow coloured solid and is stable at room temperature. It is soluble in ethanol and DMSO.

\section{Infrared spectra}

The infrared spectra of the ligand exhibited a broad meduim intensity band around $3434 \mathrm{~cm}^{-1}$ is due to intramolecular hydrogen bonded $\mathrm{OH}$ group. A very strong band occurring at $1637 \mathrm{~cm}^{-1}$ is attributed to $v_{\mathrm{C}=\mathrm{O}}$ of pyrazolone ring. A band at $1595 \mathrm{~cm}^{-1}$ in the ligand spectrum is possibly due to the vibrational stretching frequency of azomethine $v_{\mathrm{C}=\mathrm{N}}$ group.

\section{${ }^{1}$ H NMR spectra}

The ${ }^{1} \mathrm{H}$ NMR spectrum of the Ligand (Figure 1) displays the following signals: $\mathrm{C}_{6} \mathrm{H}_{5}$ as a multiplet at $6-8 \mathrm{ppm}$. $=\mathrm{C}-\mathrm{CH}_{3}$ at $2.4 \mathrm{ppm},-\mathrm{N}-\mathrm{CH}_{3}$ at $3.2 \mathrm{ppm}$ and azomethine proton at $\mathrm{CH}=\mathrm{N}-$ at $9.8 \mathrm{ppm}$, intramolecular hydrogen bonded $\mathrm{OH}$ group at $13.4 \mathrm{ppm}$.

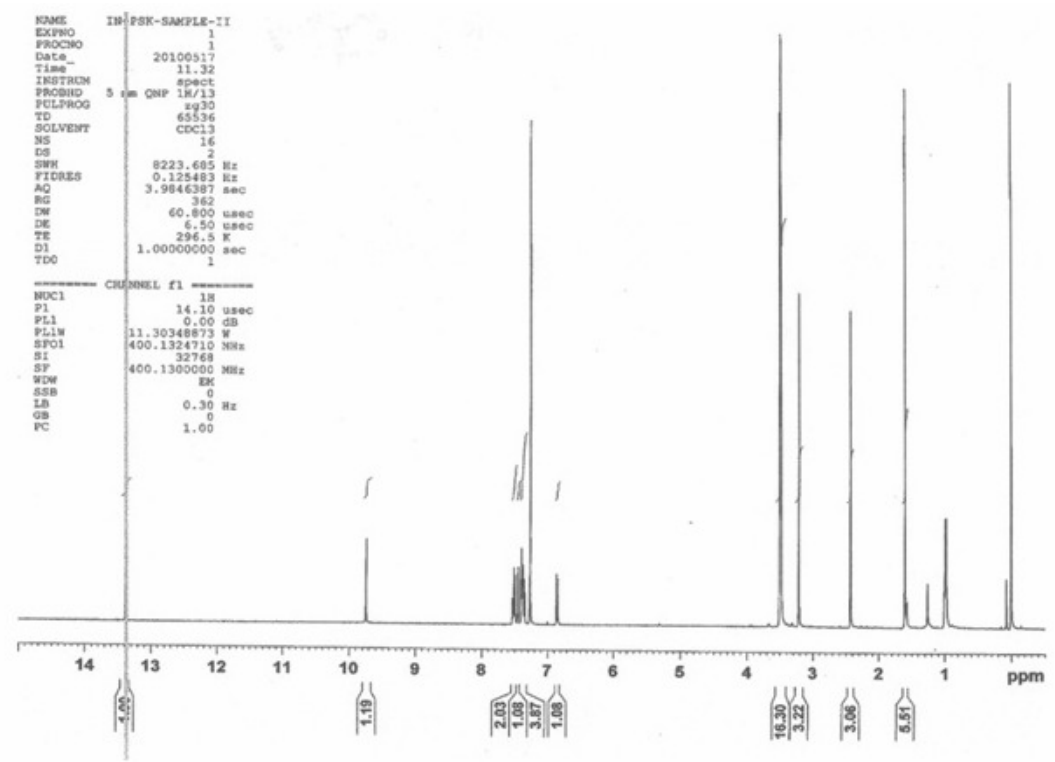

\section{${ }^{13}$ C NMR spectra}

Figure 1. ${ }^{1} \mathrm{H}$ NMR spectra of $5 \mathrm{Br}$ SALAAP

${ }^{13} \mathrm{C}$ Spectrum of Ligand (Figure 2) has 120(C-1), 160.3(C-2), 118.5(C-3) ,135.6(C-4), 115 (C-5), 133.7(C-6), 160.7(C-7), 116 (C-8), 134 (C-9), 10.27(C-10), 35.5 (C-11), 160.6 (C-12), 142 (C- 13),112 (C-14), 129(C-15), 118.9 (C-16), 129 (C-17), 112(C-18). 


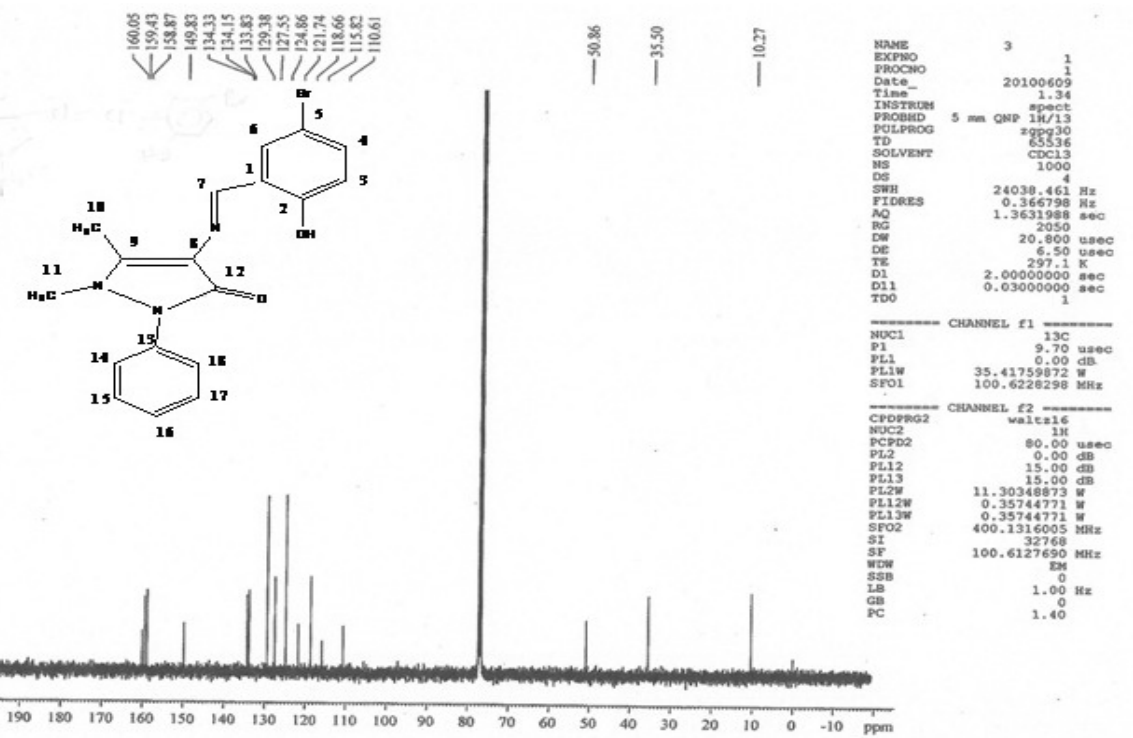

Figure 2. ${ }^{13} \mathrm{C}$ NMR spectra of 5-Br SALAAP

\section{Mass spectra}

In the ESI-mass spectrum of ligand (Figure 3), the molecular ion peak was observed at $\mathrm{m} / \mathrm{z}$ 386 which is in good agreement with the molecular weight of the proposed structure.

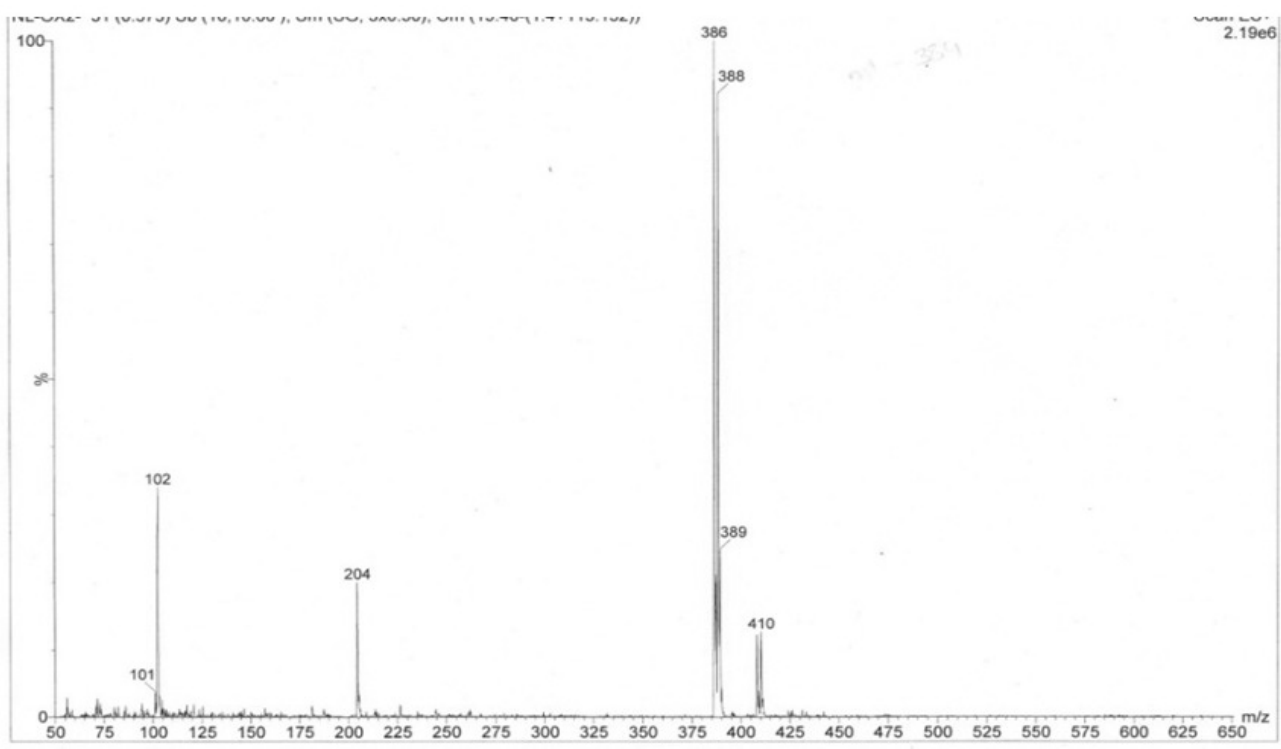

Figure 2. Mass spectra of 5-Br SALAAP

\section{Characterization of metal complexes}

We have prepared and characterized the complexes of $\mathrm{Cu}(\mathrm{II}), \mathrm{Ni}(\mathrm{II}), \mathrm{Co}(\mathrm{II})$ and $\mathrm{Zn}$ (II) and $\mathrm{VO}(\mathrm{IV})$ with 5-Br SALAAP ligand. All the complexes are stable at room temperature and non hygroscopic, insoluble in water, but soluble in DMSO and Ethanol. 
Based on the data of elemental analysis \& ESI mass, the composition assigned to the complexes, are formulated and presented in Table 1. The conductance values for all complexes were measured using DMSO solvent, the obtained low values $\left(6-11 \mathrm{Ohm}^{-1} \mathrm{~cm}^{2} \mathrm{~mol}^{-1}\right)$ suggest the presence of a non-electrolytic nature of complexes in the solvent and that no anions are present outside the co-ordination sphere.

Table 1. Analytical data of complexes

\begin{tabular}{cccccc}
\hline Complex & Formula & $\mathrm{M} . \mathrm{Wt}$ & $\mathrm{C}$ & $\mathrm{H}$ & $\mathrm{N}$ \\
\hline Ligand & $\mathrm{C}_{18} \mathrm{H}_{16} \mathrm{BrN}_{3} \mathrm{O}_{6}$ & 386 & $55.91 \%$ & $4.04 \%$ & $10.90 \%$ \\
& & & $(51.79 \%)$ & $(4.14 \%)$ & $(10.88 \%)$ \\
& & $51.34 \%$ & $3.62 \%$ & $10.23 \%$ \\
{$\left[\mathrm{Cu}(5 \mathrm{BrSALAAP})_{2}\right] \mathrm{H}_{2} \mathrm{O}$} & $\mathrm{C}_{36} \mathrm{H}_{30} \mathrm{~N}_{6} \mathrm{Br}_{2} \mathrm{CuO}_{4}$ & 834 & $(51.79 \%)$ & $(3.59 \%)$ & $(10.0 \%)$ \\
& & & $52.11 \%$ & $3.61 \%$ & $10.13 \%$ \\
{$\left[\mathrm{Ni}(5 \mathrm{BrSALAAP})_{2}\right] \mathrm{H}_{2} \mathrm{O}$} & $\mathrm{C}_{36} \mathrm{H}_{30} \mathrm{~N}_{6} \mathrm{Br}_{2} \mathrm{NiO}_{4}$ & 828 & $(52.89 \%)$ & $(3.55 \%)$ & $(10.41 \%)$ \\
& & & $52.01 \%$ & $3.62 \%$ & $10.14 \%$ \\
{$\left[\mathrm{Co}(5 \mathrm{BrSALAAP})_{2}\right] \mathrm{H}_{2} \mathrm{O}$} & $\mathrm{C}_{36} \mathrm{H}_{30} \mathrm{~N}_{6} \mathrm{Br}_{2} \mathrm{CoO}_{4}$ & 830 & $(52.04 \%)$ & $(3.61 \%)$ & $(10.12 \%)$ \\
& & & $51.11 \%$ & $3.61 \%$ & $10.09 \%$ \\
{$\left[\mathrm{Zn}(5 \mathrm{BrSALAAP})_{2}\right] \mathrm{H}_{2} \mathrm{O}$} & $\mathrm{C}_{36} \mathrm{H}_{30} \mathrm{~N}_{6} \mathrm{Br}_{2} \mathrm{ZnO}_{4}$ & 835 & $(51.73 \%)$ & $(3.59 \%)$ & $(10.05 \%)$ \\
& & & $51.14 \%$ & $3.61 \%$ & $10.03 \%$ \\
{$\left[\mathrm{VO}(5 \mathrm{BrSALAAP})_{2}\right] \mathrm{H}_{2} \mathrm{O}$} & $\mathrm{VOC}_{36} \mathrm{H}_{30} \mathrm{~N}_{6} \mathrm{Br}_{2} \mathrm{O}_{4}$ & 838 & $(51.55 \%)$ & $(3.57 \%)$ & $(10.02 \%)$ \\
\hline
\end{tabular}

\section{Infrared spectra}

The IR spectra of the complexes are compared with that of the free ligand to determine the changes that might have taken place during the complexation, all data are listed in Table 2. The band assigned to the azomethine group in the free Schiff base ligand was observed at $v_{\mathrm{C}=\mathrm{N}} 1595 \mathrm{~cm}^{-1}$ and shifted to lower or higher wave numbers ranging from $1562-1617 \mathrm{~cm}^{-1}$ in the spectra of all complexes. This indicates the participation of the nitrogen atom of the azomethine group in coordination ${ }^{13-16}$. The band at $v_{\mathrm{C}=\mathrm{O}}=1637 \mathrm{~cm}^{-1}$ is characteristic of the carbonyl group present in the free Schiff base ligand. This group was shifted to lower or higher wave numbers ranging from $1591-1641 \mathrm{~cm}^{-1}$ in all complexes, which indicates the involvement of the carbonyl oxygen in coordination ${ }^{13-15,17}$. The presence of IR broad bands of metal complexes are in the range of $2931-3419 \mathrm{~cm}^{-1}$ indicate the presence of coordinated/lattice water molecules supported from thermal analysis ${ }^{13,18}$. The $v_{\mathrm{C}-\mathrm{O}}$ (phenolic) stretching frequency of ligand is seen at $1342 \mathrm{~cm}^{-1}$, which gets shifted to higher $\left(1355-1384 \mathrm{~cm}^{-1}\right)$ region in the complexes indicating coordination of phenolic oxygen ${ }^{19}$. The IR spectra of complexes show new bands at $552-573 \mathrm{~cm}^{-1}$ and $429-473 \mathrm{~cm}^{-1}$ assigned to $v_{(\mathrm{M}-\mathrm{O})}$ and $v_{(\mathrm{M}-\mathrm{N})}$ respectively ${ }^{20}$. The peak observed at $987 \mathrm{~cm}^{-1}$ complexes of VO are due to $v_{(\mathrm{V}=\mathrm{O})}$.

Table 2. IR spectral data of ligand and its complexes in $\mathrm{cm}^{-1}$

\begin{tabular}{cccccccc}
\hline Complex & $v_{\mathrm{O}-\mathrm{H}}$ & $v_{\mathrm{C}=\mathrm{N}}$ & $v_{\mathrm{C}=\mathrm{O}}$ & $v_{\mathrm{C}-\mathrm{O}}$ & $v_{\mathrm{M}-\mathrm{O}}$ & $v_{\mathrm{M}-\mathrm{N}}$ & $v_{\mathrm{V}=\mathrm{O}}$ \\
\hline Ligand & 3434 & 1595 & 1637 & 1342 & --- & --- & ---- \\
$\mathrm{Cu}(\mathrm{II})$ Complex & 2931 & 1617 & 1653 & 1384 & 556 & 450 & ---- \\
$\mathrm{Ni}(\mathrm{II})$ Complex & 3383 & 1562 & 1591 & 1379 & 553 & 499 & ---- \\
$\mathrm{Co}(\mathrm{II})$ Complex & 3382 & 1561 & 1596 & 1343 & 555 & 448 & ---- \\
$\mathrm{Zn}(\mathrm{II})$ Complex & 3347 & 1575 & 1609 & 1355 & 552 & 429 & ---- \\
$\mathrm{VO}(\mathrm{IV})$ Complex & 3419 & 1582 & 1641 & 1375 & 573 & 473 & 987 \\
\hline
\end{tabular}




\section{Electronic spectra and magnetic susceptibility}

The electronic spectral data and magnetic moments ( $\mu_{\text {eff }}$ B.M) of the complexes are presented in Table 3. The electronic absorption spectra of ligand and metal complexes were recorded in DMSO, in the range of 200-1100 $\mathrm{nm}$. The electronic spectrum of free Schiff base showed three bands at $297 \mathrm{~nm}, 347 \mathrm{~nm}$ and $407 \mathrm{~nm}$ are due to $\pi \rightarrow \pi^{*}$ and n- $\pi^{*}$ transitions ${ }^{13}$.

$\mathrm{Cu}(\mathrm{II})$ complex displayed four bands at $302 \mathrm{~nm}, 357 \mathrm{~nm}, 427 \mathrm{~nm}$ and $580 \mathrm{~nm}$. The first two peaks are most probably due to ligand $\rightarrow$ metal charge -transfer transitions. The last two peaks are due to $\mathrm{d}-\mathrm{d}$ transitions, which is assigned ${ }^{2} \mathrm{E}_{\mathrm{g}} \rightarrow{ }^{2} \mathrm{~T}_{2 \mathrm{~g}}$ suggesting tetragonal geometry (distorted octahedral geometry) ${ }^{21}$. The magnetic moment of $\mathrm{Cu}(\mathrm{II})$ was seen at 1.72 B.M. On the basis of electronic spectra and magnetic susceptibility measurements, a distorted octahedral geometry around $\mathrm{Cu}(\mathrm{II})$ is suggested.

The electronic spectra of $\mathrm{Ni}(\mathrm{II})$ complex displayed four bands at $302 \mathrm{~nm}, 347 \mathrm{~nm}$, $457 \mathrm{~nm}$ and $705 \mathrm{~nm}$. The first two peaks are most probably due to ligand $\rightarrow$ metal charge transfer transitions. The last two peaks are due to d-d transitions and are assigned as ${ }^{3} \mathrm{~A}_{2 \mathrm{~g}}(\mathrm{~F}) \rightarrow{ }^{3} \mathrm{~T}_{1 \mathrm{~g}}(\mathrm{P})$ and ${ }^{3} \mathrm{~A}_{2 \mathrm{~g}} \rightarrow{ }^{3} \mathrm{~T}_{1 \mathrm{~g}}(\mathrm{~F})$ respectively. This suggests an octahedral geometry ${ }^{21-24}$ around $\mathrm{Ni}(\mathrm{II})$ ion.

The magnetic moment of $\mathrm{Ni}(\mathrm{II})$ complex was found to be $2.87 \mathrm{~B} . \mathrm{M}$ which are in the normal range observed for octahedral $\mathrm{Ni}(\mathrm{II})$ complexes. The electronic spectrum of the Co(II) complex exhibited four bands at $297 \mathrm{~nm}, 347 \mathrm{~nm}, 437 \mathrm{~nm}$ and $634 \mathrm{~nm}$. The first two intense maxima are due to intra-ligand transitions of the organic moiety.

The other two transitions may be assigned to ${ }^{4} \mathrm{~T}_{1 \mathrm{~g}} \rightarrow{ }^{4} \mathrm{~T}_{1 \mathrm{~g}}(\mathrm{P})$ and ${ }^{4} \mathrm{~T}_{1 \mathrm{~g}}(\mathrm{~F}) \rightarrow{ }^{4} \mathrm{~T}_{2 \mathrm{~g}}(\mathrm{~F})$ respectively, suggesting an octahedral geometry around $\mathrm{Co}$ (II) ion ${ }^{25}$. The magnetic moment of $\mathrm{Co}$ (II) complex which was found to be 5.14 B.M. is also an indicative of octahedral geometry ${ }^{26}$.

The $\mathrm{Zn}(\mathrm{II})$ complex has been found to be diamagnetic in nature. On the basis of analytical, conductance and spectral data, the $\mathrm{Zn}$ complex, assigned to be an octahedral geometry ${ }^{27}$. The observed magnetic moment value for VO(IV) complex is 1.91 B.M. which suggests octahedral geometry for this complex ${ }^{28}$. In the present studies, VO(IV) complex shows four bands at $307 \mathrm{~nm}, 347 \mathrm{~nm}, 452 \mathrm{~nm}$ and $527 \mathrm{~nm}$. The first two intense maxima are due to intra-ligand transitions of the organic moiety. The other two transitions may be due to ${ }^{2} \mathrm{~B}_{2} \rightarrow{ }^{2} \mathrm{~B}_{1}$ and ${ }^{2} \mathrm{~B}_{2} \rightarrow{ }^{2} \mathrm{~A}_{1}$. The low frequency band corresponding to ${ }^{2} \mathrm{~B}_{2} \rightarrow{ }^{2} \mathrm{E}$ is not clearly resolved in the spectrum. Based on the two bands observed, octahedral geometry is proposed for the above complex ${ }^{29}$.

Table 3. Electronic spectra and magnetic susceptibility data for ligand and complexes

\begin{tabular}{ccc}
\hline Complex & Absorption, nm & $\mu_{\text {eff }}(\mathrm{B} . \mathrm{M})$ \\
\hline Ligand & $297,347,407$ & - \\
Cu(II) complex & $302,352,427,580$ & 1.72 \\
Ni(II) complex & $302,347,457,705$ & 2.87 \\
Co(II) complex & $297,347,437,634$ & 5.14 \\
Zn(II) complex & - & dia \\
VO(IV) complex & $307,347,452,527$ & 1.91 \\
\hline
\end{tabular}

\section{ESR spectra}

The ESR spectra of the Cu(II) complex (Figure 4) was recorded on Jeol, JES -FA 200 ESR spectrometer at R.T. The observed data for complex showed that $\mathrm{g}_{\Pi}=2.07-2.543$ and $\mathrm{g}_{\perp}=2.22$. This complex showed $\mathrm{g}_{\Pi}>2.3$ which is characteristic of anion environment. The 
trend $\mathrm{g}_{\Pi}>\mathrm{g}_{\perp}>2.0023$ observed for the complexes indicates that unpaired electron is localised in $\mathrm{d}_{\mathrm{x}-\mathrm{y}}^{2}{ }^{2}$ orbital of the $\mathrm{Cu}(\mathrm{II})$ ion. Thus a tetragonal geometry is proposed for the complex. $\mathrm{G}=\left(\mathrm{g}_{\Pi}-2\right) /(\mathrm{g} \perp-2)$, which measure the exchange interaction between the metal centres in a polycrystalline solid has been calculated. Acc to Hathaway ${ }^{30}$ if $\mathrm{G}>4$ the exchange interaction is negligible if $\mathrm{G}<4$ indicates considerable exchange interaction in the solid complexes. The above reported complex showed $\mathrm{G}$ values $<4$ indicating the exchange interaction in complex. Furthr more, Masa cesi et $a l^{31}$ reported that $\mathrm{g}_{\Pi}$ is 2.4 for copperoxygen bonds and 2.3 for copper -nitrogen bonds. for the complex reported here, $\mathrm{g}_{\Pi}$ values between $2.3-2.4$ which further confirms , the presence mixed copper- nitrogen and copper oxygen bonds in these chelate complex.

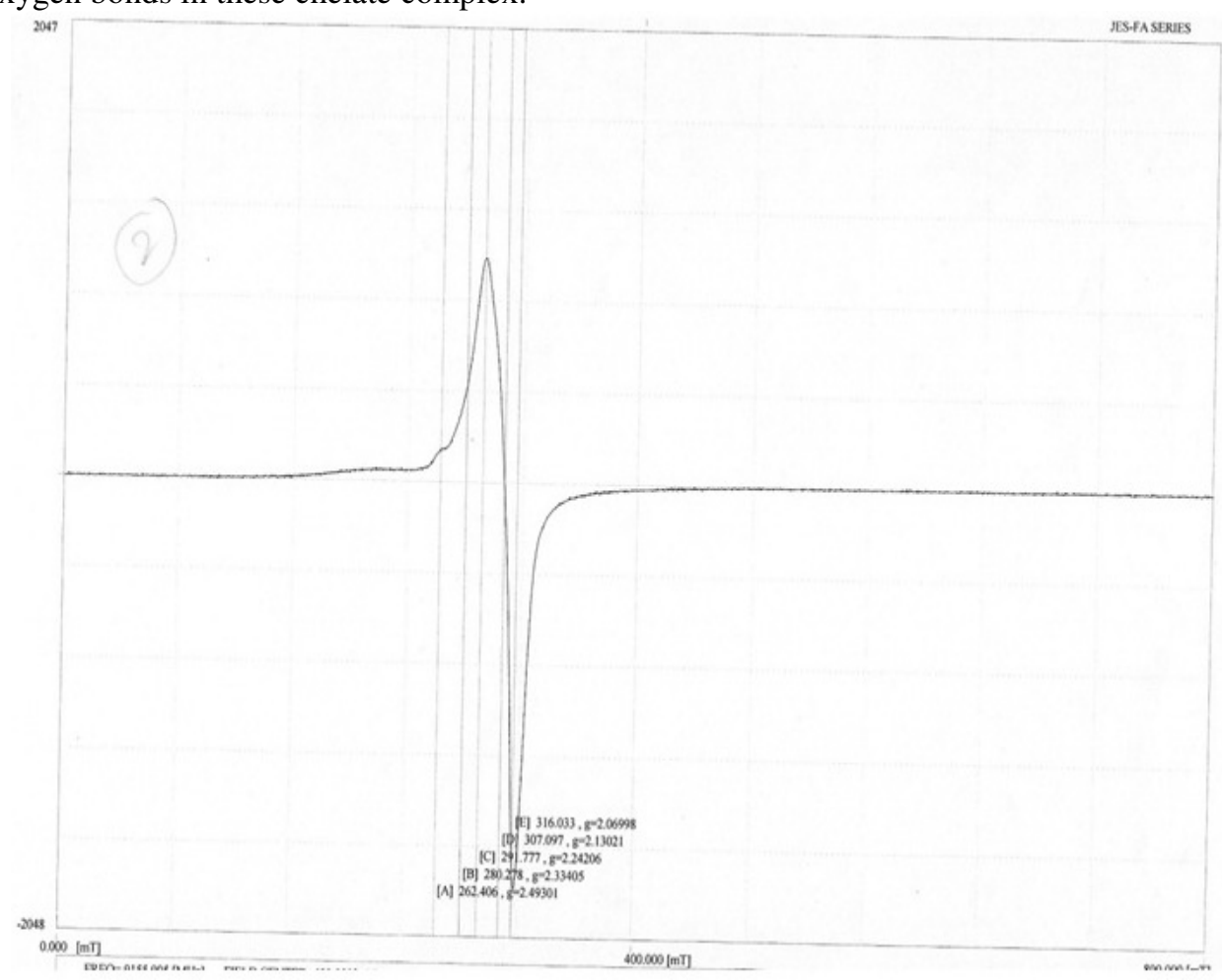

Figure 4. ESR spectra of $\mathrm{Cu}(\mathrm{II})$ complex

\section{Thermal analysis}

In the present investigation heating rates were suitably controlled at $10{ }^{0} \mathrm{C} \mathrm{min}^{-1}$ under nitrogen atmosphere and the weight loss was measured from the ambient temperature up to $1000{ }^{0} \mathrm{C}$. Water molecules in complexes are generally of two types lattice water and coordinated water ${ }^{32}$. The lattice water will be lost at low temperature $\left(60-120^{\circ} \mathrm{C}\right)$ where as the loss of coordinated water molecule is observed at high temperatures $\left(150-200^{\circ} \mathrm{C}\right)$. In the thermograms of DTA and TGA of complexes [Co(II)(5-BrSALAAP $\left.)_{2}\right] \mathrm{H}_{2} \mathrm{O}$, [VO(IV) (5-Br SALAAP $)_{2}$ ] $\mathrm{H}_{2} \mathrm{O}$, (Figure 5 \& 6) a small weight loss in the range of $60-120{ }^{\circ} \mathrm{C}$ is assigned to loss of lattice water, maximum and gradual weight loss in the range of $300-1000{ }^{\circ} \mathrm{C}$ is and attributable to decomposition of ligand moiety. The residue at $1000{ }^{\circ} \mathrm{C}$ indicates the non volatile metal component present in the complex. 


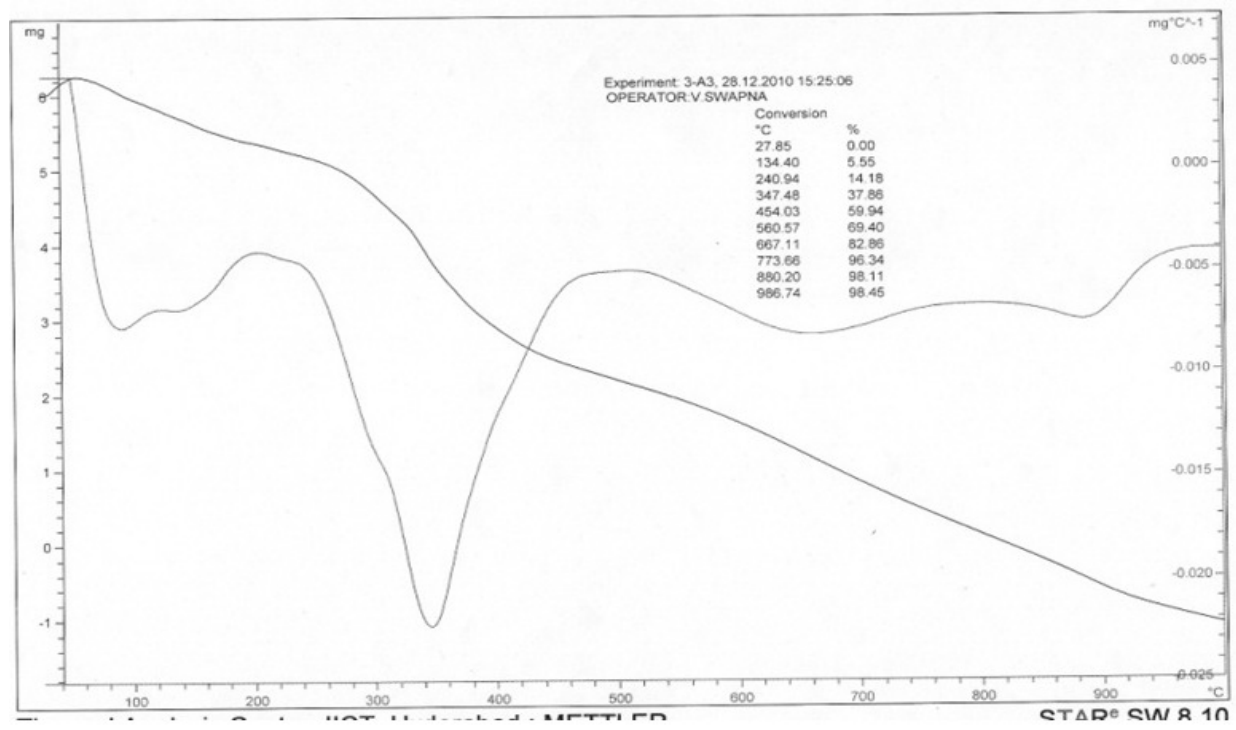

Figure 5. Thermogram of $\mathrm{Cu}(\mathrm{II})$ complex

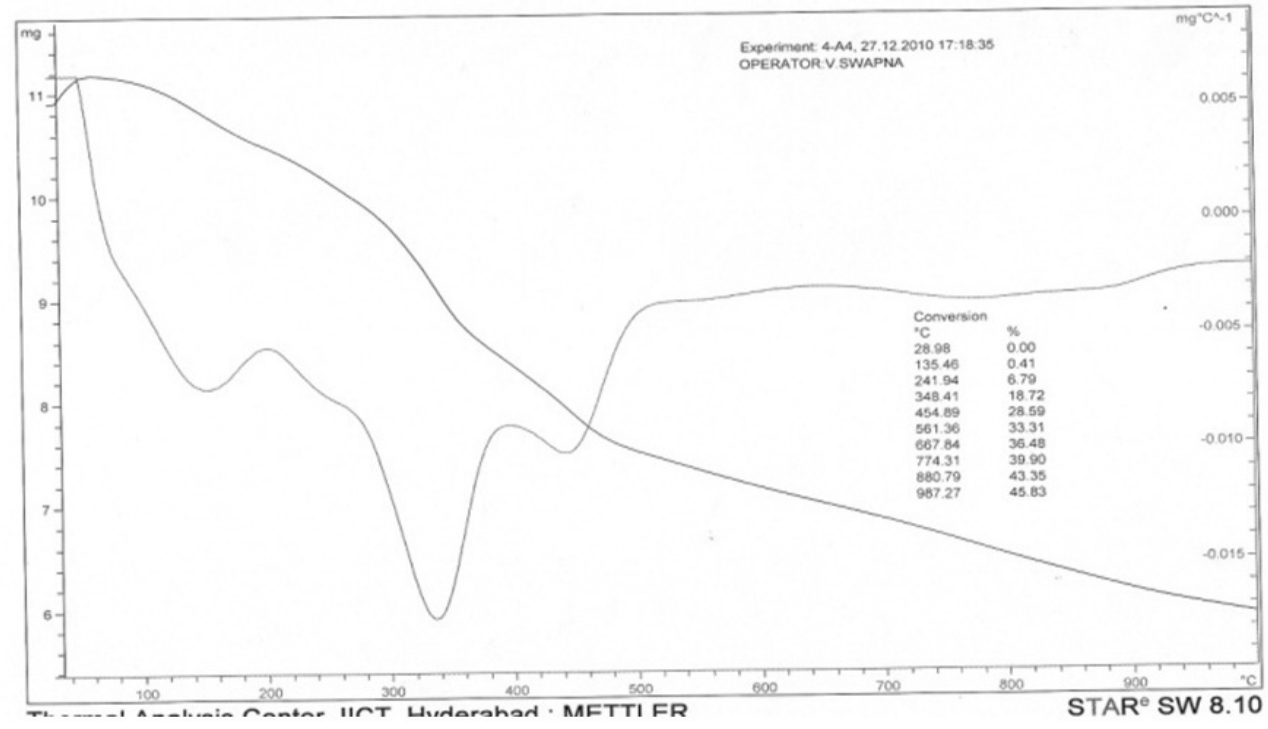

Figure 6. Thermogram of VO(IV) complex

\section{Mass spectra}

Mass spectra of complexes provides a vital clue for elucidating the structure of compounds. The ESI mass of the ligands and its metal complexes recorded at room temperature were used to compare their stoichiometry.

The molecular ion peaks of $\mathrm{Cu}(\mathrm{II}), \mathrm{Ni}(\mathrm{II})$ and $\mathrm{Co}(\mathrm{II})$, (Figure 7) $\mathrm{Zn}(\mathrm{II})$ and $\mathrm{VO}(\mathrm{IV}$ ) complexes were observed respectively at $834,828,830,835$ and 838 and which were in good agreement with the molecular weight of the proposed structures and few un identified ions were also observed. 


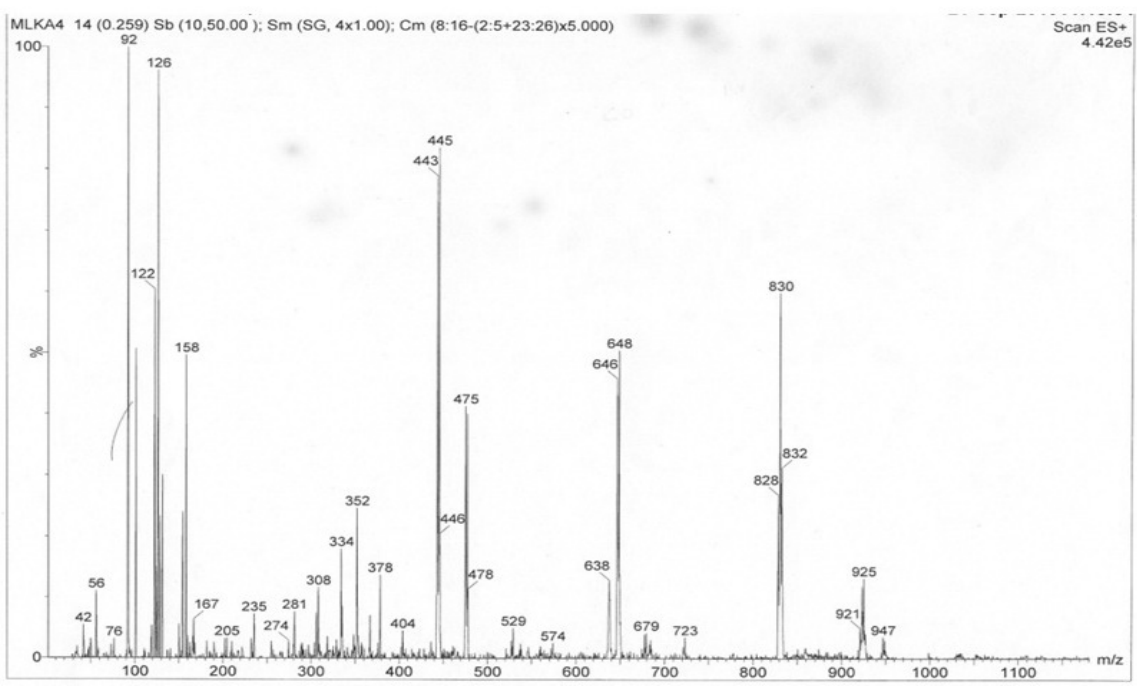

Figure 7. Mass spectrs of Co(II) complex

\section{Antimicrobial activity}

In the present investigation, biological activity of the ligand and their complexes with $\mathrm{Cu}(\mathrm{II}), \mathrm{Ni}(\mathrm{II}), \mathrm{Co}(\mathrm{II}), \mathrm{Zn}(\mathrm{II})$ and $\mathrm{VO}(\mathrm{IV})$ have been screened for antimicrobial activity against bacteria (E.coli and S.aureus) by paper disc method. The concentration for these samples maintained as $200 \mu \mathrm{g} / \mathrm{mL}, 100 \mu \mathrm{g} / \mathrm{mL}$ and $50 \mu \mathrm{g} / \mathrm{mL}$ in DMSO. In the present study the zones of inhibition of antibacterial activity have been presented in Table 4. The results indicate that copper and cobalt complexes show activity against E.coli and S. aureus at 200 $\mu \mathrm{g} / \mathrm{mL}$ (Figure 8).

Table 4. Antimicrobial acivity of complexes (inhibition of growth)

\begin{tabular}{ccccccc}
\hline \multirow{2}{*}{ Complex } & $\begin{array}{c}\text { E.coli } \\
200 \mu \mathrm{g} / \mathrm{mL}\end{array}$ & $\begin{array}{c}\text { S.aureus } \\
200 \mu \mathrm{g} / \mathrm{mL}\end{array}$ & $\begin{array}{c}\text { E.coli } \\
100 \mu \mathrm{g} / \mathrm{mL}\end{array}$ & $\begin{array}{c}\text { S.aureus } \\
100 \mu \mathrm{g} / \mathrm{mL}\end{array}$ & $\begin{array}{c}\text { E.coli } \\
50 \mu \mathrm{g} / \mathrm{mL}\end{array}$ & $\begin{array}{c}\text { S.aureus } \\
50 \mu \mathrm{g} / \mathrm{mL}\end{array}$ \\
\hline Ligand & ---- & ---- & ---- & ---- & ---- & ---- \\
$\mathrm{Cu}(\mathrm{II})$ Complex & $+\mathrm{ve}$ & $+\mathrm{ve}$ & ---- & --- & ---- & ---- \\
$\mathrm{Ni}(\mathrm{II})$ Complex & ---- & ---- & --- & ---- & --- & ---- \\
$\mathrm{Co}(\mathrm{II})$ Complex & $+\mathrm{ve}$ & $+\mathrm{ve}$ & ---- & ---- & ---- & ---- \\
Zn(II)Complex & ---- & ---- & ---- & --- & ---- & ---- \\
VO(IV)Complex & ---- & --- & ---- & ---- & ---- & ---- \\
DMSO Control & ---- & ---- & ---- & ---- & --- & --- \\
\hline
\end{tabular}

$+v e$ indicates inhibition of growth around the paper disc --- indicates no inhibition growth

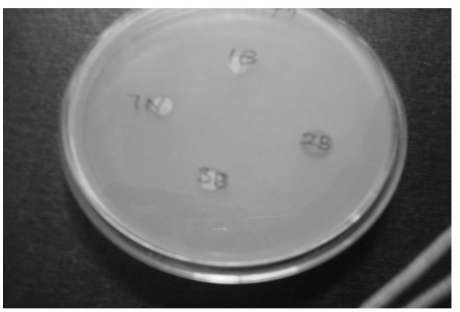

Figure 8. $\mathrm{Cu}$ (II) \& $\mathrm{Co}$ (II) complex inhibition zone of S.aureus 


\section{DNA binding activity}

In general, complexes with aromatic moieties which bind to DNA through intercalation usually results in hypochromism and bathochromism, due to the stacking interaction between aromatic chromophore of the complexes and the base pairs of DNA. The absorption spectra of the complex, Co(II)-5-Br SALAAP in the absence and presence of calf thymus DNA are illustrated in Figure 9. In the presence of DNA, decrease of peak intensities were observed in the absorption spectra of complexes. Hypochromism was suggested to be due to the interaction between the electronic state of the intercalating chromophore and that of the DNA bases ${ }^{33-37}$.

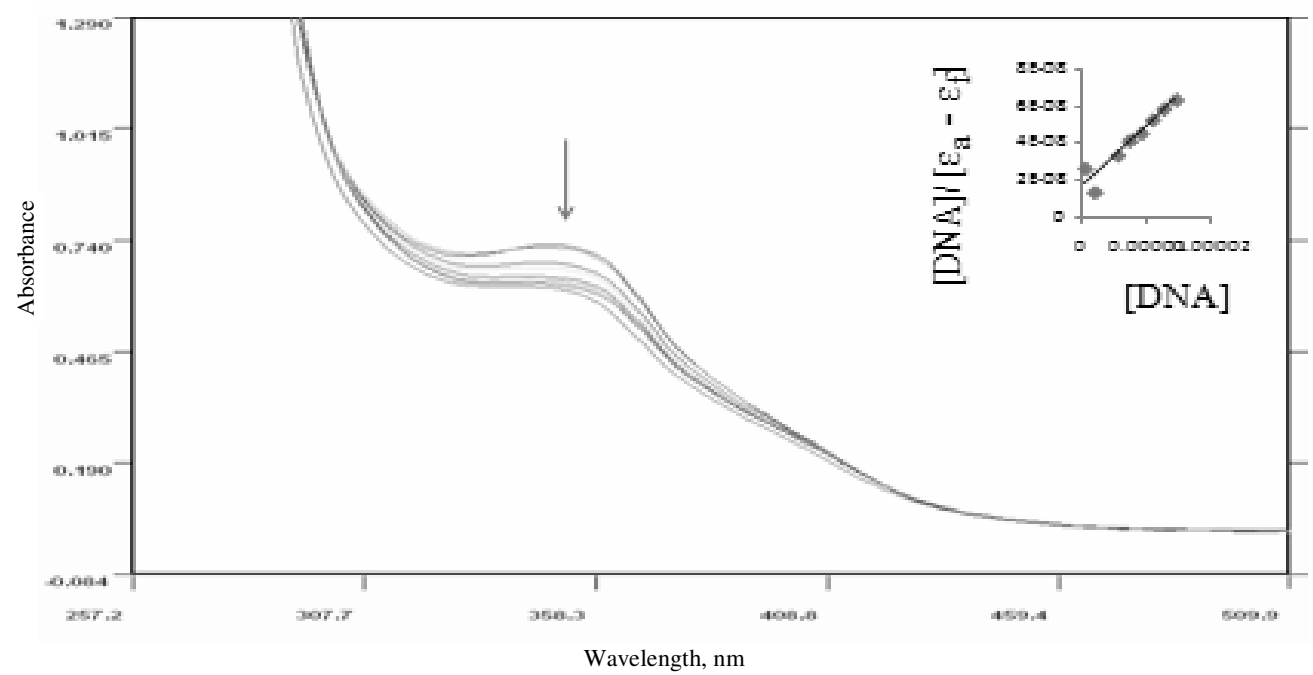

Figure 9. Absorption spectra of $\left[\mathrm{Co}(\mathrm{II})(5-\mathrm{Br} \mathrm{SALAAP})_{2}\right]$ in the absence and presence of increasing amounts of DNA, $[\mathrm{Co}]=100 \mu \mathrm{M}$, with increasing DNA concentration from 0-40 $\mu \mathrm{M}$. (Arow $(\downarrow)$ shows the absorbance changes upon increasing DNA concentration. In side: Linear plot for the calculation of the intrinsic DNA binding constant $K_{b}$ )

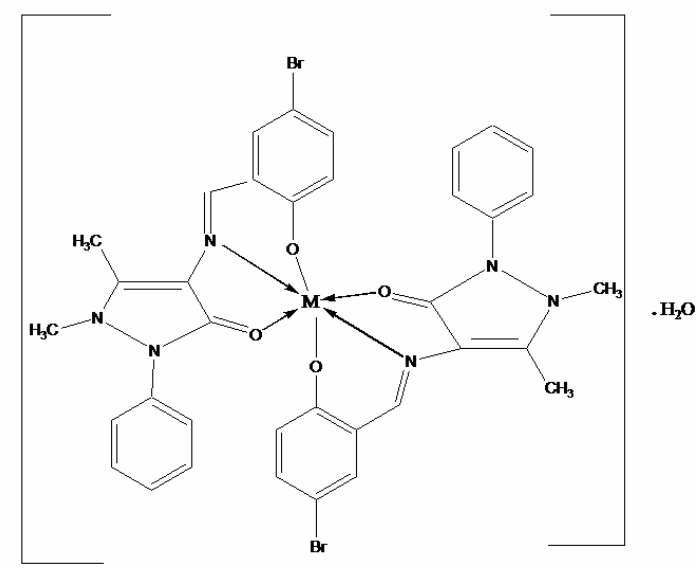

Figure 10. Proposed structures of metal complexes ( $\mathrm{M}=\mathrm{Cu}(\mathrm{II}), \mathrm{Ni}(\mathrm{II}), \mathrm{Co}(\mathrm{II}), \mathrm{Zn}(\mathrm{II})$ and VO(IV)) 
In addition to the decrease in intensity, a small red shift (bathochromism) was also observed in the spectra. These spectral changes are consistent with the intercalation of complexes into the DNA base stack. The plot of the absorption titration data according to equation $[\mathrm{DNA}] /\left(\boldsymbol{\varepsilon}_{\mathrm{a}}-\varepsilon_{\mathrm{f}}\right)=[\mathrm{DNA}] /\left(\varepsilon_{\mathrm{b}}-\varepsilon_{\mathrm{f}}\right)+1 / \mathrm{K}_{\mathrm{b}}\left(\varepsilon_{\mathrm{b}}-\varepsilon_{\mathrm{f}}\right)$ gave a linear plot and resulted in an intrinsic binding constant $\left(\mathrm{K}_{\mathrm{b}}\right) 1 \times 10^{5} \mathrm{M}^{-1}$ for $\mathrm{Co}(\mathrm{II})$ complex.

\section{Molecular modelling studies}

The possible geometries of metal complexes were evaluated (Figure 11 \& 12) using the molecular calculation with arguslab ${ }^{38}$ software. Initially the atomic charges of each complex were calculated by a semiempirical method. The structures using the standard force field included in the package, further refinement was done for the complexes. The refined structures were screened on the basis of the lowest strain energy. The energies of the resulting systems were calculated using $\mathrm{UFF}^{38-44}$.

\section{Molecular modelling structures}

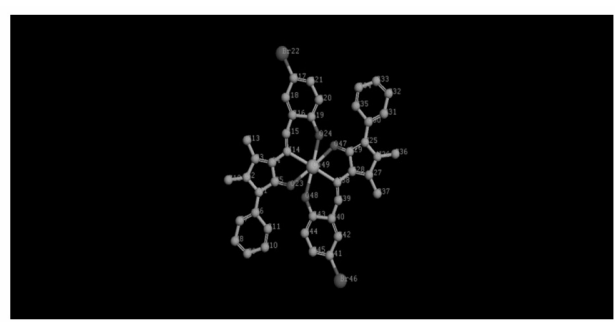

Figure 11. $\mathrm{Cu}(\mathrm{II})$ complex

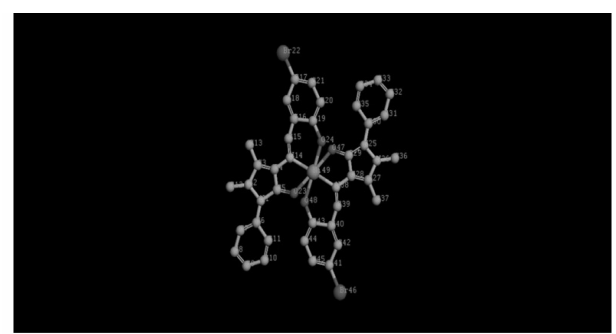

Figure 12. $\mathrm{Nu}(\mathrm{II})$ complex

\section{Conclusion}

The metal chelates of ligand have been structurally characterized. The complexes of the ligand are non electrolytes in DMSO. This ligand act as tridentate, coordinating through nitrogen of azomethine, phenolic oxygen and carbonyl of antipyrine ring respectively. Geometries of the metal complexes are assigned,based on analytical, conductance, magnetic and electronic spectral data. Biological studies of these complexes reveal that they show better activity when compared to that of the ligand.

\section{Acknowledgment}

The authors acknowledge the help of the Department of Microbiology, Osmania University, Hyderabad,in undertaking the antibacterial studies.

\section{References}

1. Turan -Zitouni G, Sivaci M, Kilic F S and Erol K, Eur J Med Chem., 2001, 36, 685.

2. Sondhi S M, Sharma V K, Singhal N, Verma R P, Shukla R, Raghubir R and Dubey M P, Phosphorous Sulfer Silicon Relat Elem., 2000, 156, 21.

3. Yoshioka S, Ogata H, Shibazaki T and Ejima A, Chem Pharm Bull., 1981, 29, 1179.

4. Burdulene D, Palaima A, Stumbryavichyute Z and Talaikite Z, Pharm Chem J., 1999, 33, 191.

5. Evstopov A N, Yavorovskaya V E, Vorobev E S, Kudonogova Z P, Gritsenko L N, Schmidt,E N, Medvedeva SG, Filimonov D V, PrishchepT P and Saratikov A S, Pharm Chem J., 1992, 26, 426.

6. Sayed G H, Radwan A, Mohamed S M, Shiba S A and Kalil M, Chin J Chem., 1992, 10, 475-480.

7. Cosmetic, Toiletry and Fragrance Association, J Am Coll Toxicol., 1992, 11, 475-488.

8. Verleye M, Heurald I and Gillardin J M, Pharmacol Res., 2000, 41, 539-542. 
9. Saraswathi K, Naidu N V S, Kumari K M and Padmaja K P, Chem Environ Res., 1999, 8, 271-277.

10. Singh L, Sharma A and Sindhu S K, Asian J Chem., 1999, 11, 1445.

11. Zhang Y, Yzhi L, Hanbin T and Longgen Z, Acta Crystallogr E, 2002, 58, 24.

12. Harikumaran Nair M L, Pramila Gladis M S and Sheela A, J Indian Chem Soc., 2007, 84, 329.

13. Abd El-Waheb Z H, Mashaly M M and Faheim A A, Chem Pap., 2005, 59(1), 25-36.

14. Radmakrishnan T, Joseph P T and Prabhakaran C P, J Inorg Nucl Chem., 1976, 38, 2217.

15. Shankar G, Premkumar R R and Ramalingam S K, Polyhedron, 1986, 5, 991.

16. Ali M A, Mirza A H, Nazimuddin M, Dhar P K and Butcher R J, Transition Met Chem., 2002, 27, 27-33.

17. Ramesh R, Suganthy P K and Natarajan K, Synth React Inorg Met-Org Chem., 1996, 26, 47.

18. Jezowska Trzebiatowska B, Lisowski J, Vogt A and Chmielewski P, Polyhedron, 1988, 7, 337.

19. Lindoy L F, Moody W E and Taylor D, Inorg Chem., 1997, 16, 1962.

20. Nakamoto K, Infrared and Raman Spectra of Inorganic and coordination compounds, $3^{\text {nd }}$ Ed., Wile, New York, 1997.

21. Raman N, Kulaindaisamy A and Jeyasubramanian K, Synth React Inorg Met -Org Nano -Metal Chem., 2009, 32(9), 1583.

22. Dunn T M, The Visible and Ultraviolet Spectra of Complex Compounds; Lewis J and Wilkinson R G, Interscience, New York, 1960.

23. Narang K K, Singh K M, Singh V P, Tare V B and Gogiani A K, Synth React Inorg Met Org Chem., 1990, 20(8), 1125.

24. Shakir M, Mohammed A K and Nasman O S M, Polyhedron, 1996, 15, 3487-3492.

25. Mukherji G, Poddar S N and Dey K, Indian J Chem., 1996, 25A, 275.

26. Mondal N ,Dey D K, Mitra S and Abdul Malik K M, Polyhedron, 2000, 19, 2707.

27. Imran M ,Iqbal J, Iqbal S and Ijaz N, Turk Biol., 2007, 31, 67-72.

28. Maurya R C and Mishra D D, Synth Inorg Met Org Chem., 1995, 27, 1127.

29. Muller A, Krishna rao V V and Diemann E, Chem Ber., 1971, 104, 461.

30. Hathway B J, Bardley G N and Gillard R D, Eds., Essays in Chemistry, Academic Press, New York, USA, 1971.

31. Suresh Babu V, Ramesh A, Raghuram P and Raghava Naidu R, Polyhedron, 1997, 16, 607.

32. Nikolaev A V, Myachina L I and Logvinenko V A, Thermal Anal., 1969, 2, 779.

33. Long E.C and Barton J K, Acc Chem Res., 1990, 23, 271-273.

34. Dougherty G and Pigram W J, Crit Rev Biochem., 1982, 12, 103-132.

35. Berman H M and Young P R, Annu Rev Biophys Bioeng., 1981, 10, 87-114.

36. Cantor C and Schimmel P R, Biophysical Chemistry, Freeman W H: San Francisco, 1980, $2,398$.

37. Tysco T A, Morgan R J, Baker A D and Strekas T C, J Phy Chem., 1993, 97, 1707-1711.

38. Arguslab 4.0 Marky Thomson, Planaria software IC, Seattle, WA; www.arguslab.com

39. Thompson M.A and Zerner M.C, J Am Chem Soc., 1991, 113, 8210.

40. Mark A Thompson, Eric D. Glendening and David Feller, J Phys Chem., 1996, 98, 10465.

41. Rappe A.K, Casewit C J, Colwell K S, Goddard III W A and Skiff W M, JACS., 1992, 114, 10024-10035.

42. Casewit C J, Colwell K S and Rappe A K, JACS, 1992, 114, 10046.

43. Rappe A K and Goddard W A, JPC., 1991, 95, 3358-3363.

44. Rappe A K, Colwell K S and Casewit C, J Inorg Chem., 1993, 32, 3438. 


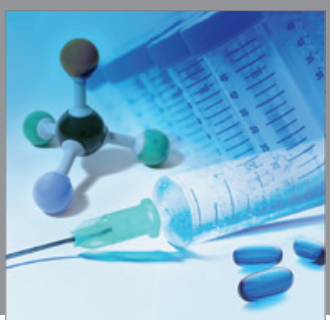

International Journal of

Medicinal Chemistry

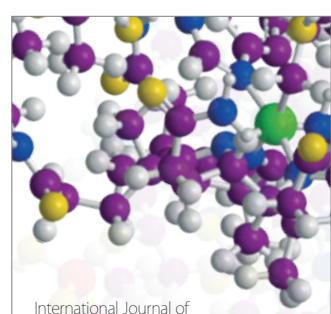

Carbohydrate Chemistry

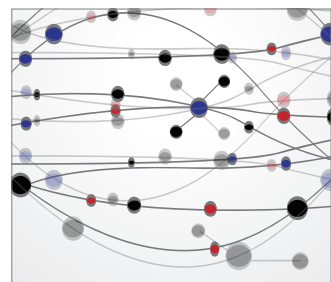

The Scientific World Journal
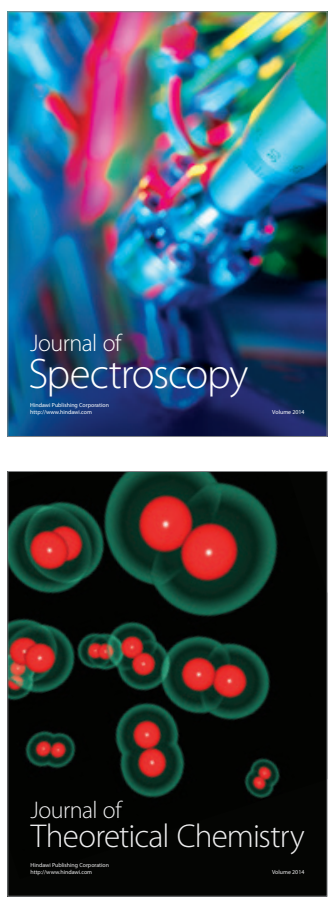
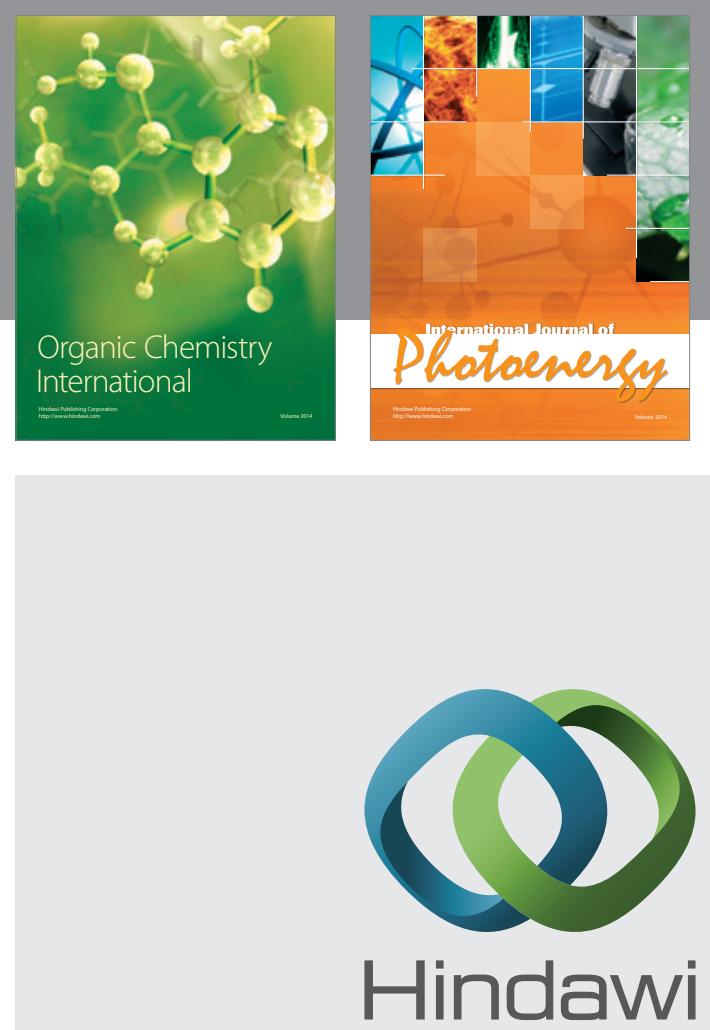

Submit your manuscripts at

http://www.hindawi.com
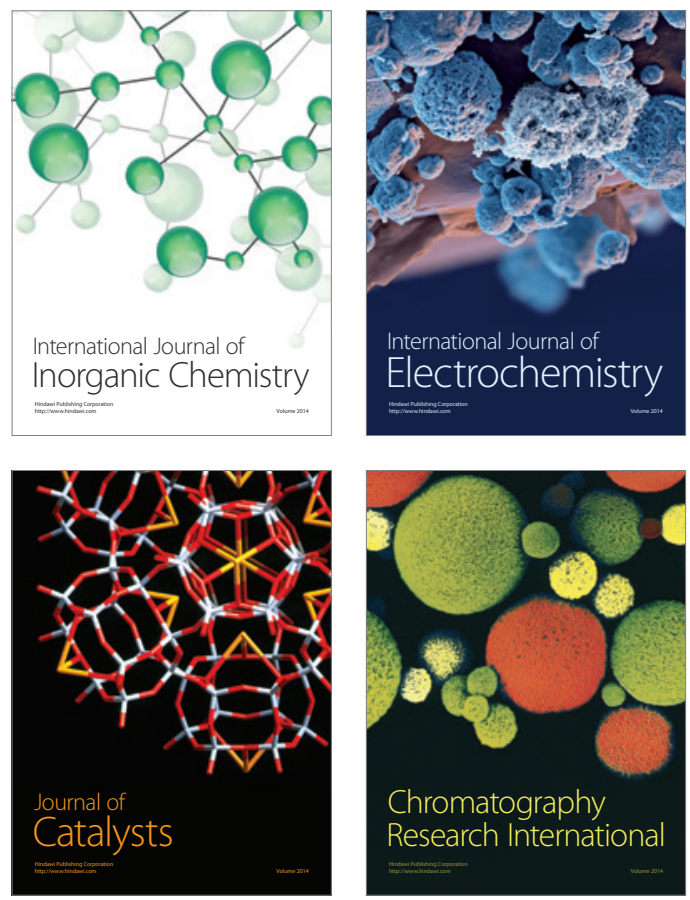
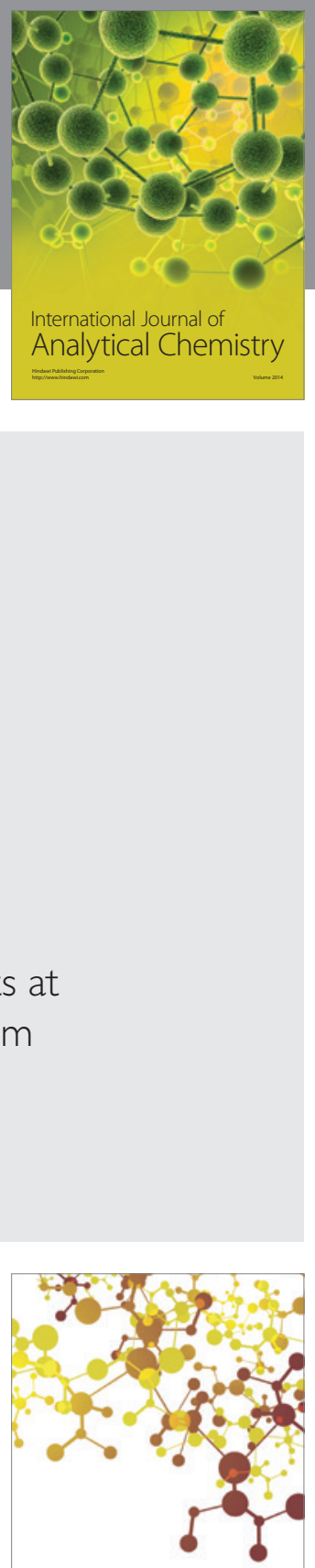

Journal of

Applied Chemistry
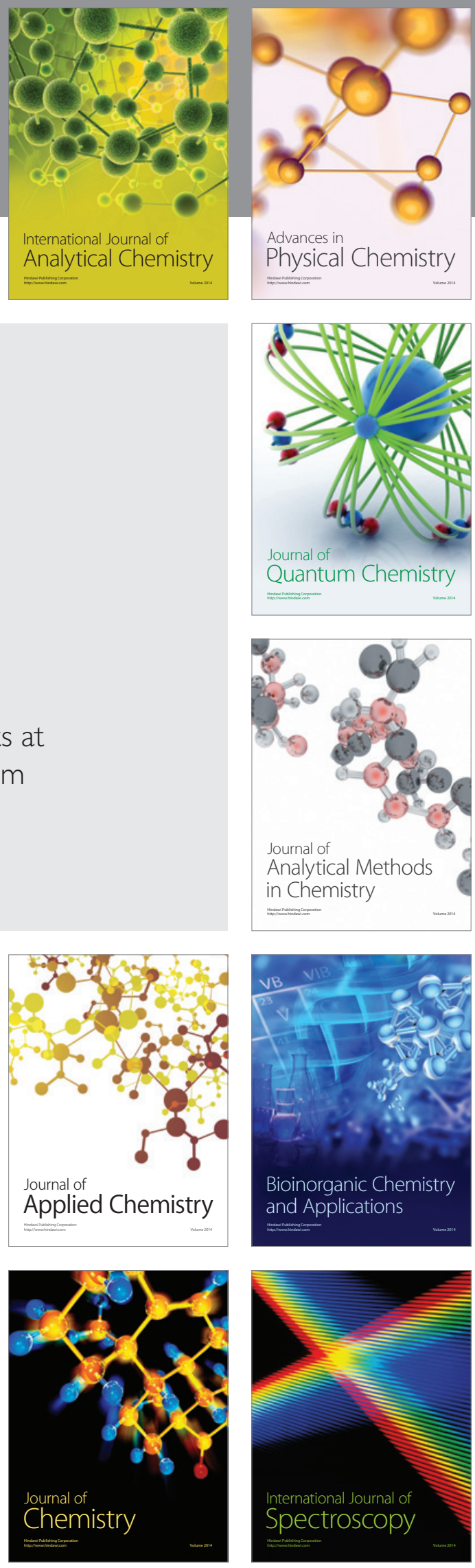